\title{
The Women as a Commodity and Marriage as a Commercial Opportunity: An Investigation into the Unpleasant Truth of Marriage Trafficking in India
}

\author{
Dr. Sasmita Patel*, Arya CC** \\ *Assistant Professor at Department of Social Work, Visva-Bharati (A Central University), Santiniketan, \\ West Bengal, India \\ **Research Scholar at Department of Social Work, Visva-Bharati (A Central University), Santiniketan, \\ West Bengal, India \\ Corresponding Author: Arya CC
}

DOI: https://doi.org/10.52403/ijrr.20220180

\begin{abstract}
This study investigates the unpleasant truth of marriage trafficking in India and how our society perceives women as commodities and makes marriage a commercial opportunity. As per the 2011 Census, India has $48.04 \%$ women of the total population; their social status is not satisfactory. If we take the words of Mahatma Gandhi, "the progress of the country is determined by the social status of women in the country,"; and it is unfortunate to say that, for women, India is not a safer place. Brides from economically deprived regions of east and south India are purchased for marriages. Girls are trafficked and sold by spouses and agents to men looking for girls to marry. These brides are tightly controlled so that they do not escape. They use to go through difficult phases of life as they cannot make their own choices, do not enjoy the rights of even being an individual, and are considered slaves. A girl, who should be in school at the young age of 14 or 15 to develop herself and put effort to lead her future in the right direction with fair chances made accessible to her, is compelled into the so-called institution of marriage with men double or triple her age. Certain girls labor as domestic slaves during the day and forced prostitution at night reveal their awful situation.

This is a research study completely based on secondary sources. As mentioned above, it has tried to review and analyze the condition of women after marriage trafficking in Indian scenario from the wider perspectives. The
\end{abstract}

available journals articles, books, newspapers and other e-resources on the subject are looked into with a critical analysis on every nuance of bride trafficking in India. The whole discussion and findings are categorized under different themes based on the three sole objectives of the study such as understanding the contributing factors, the further consequences of bride trafficking in Indian scenarios, and critically analyzing the existing legislations and provisions related to trafficking in India.

Keywords: Marriage trafficking, Commodity, Commercial Opportunity, Forced Prostitution, Domestic Violence

\section{INTRODUCTION}

Bill Flores says "imagine having all of your freedoms taken away, being forced to work against your will, and constantly living under the threat of violence - in short, being forced to live as a slave. Sadly, this situation is a reality for millions of children, women, and men each year as part of the global human trafficking industry" (Sorensen, 2019). Human trafficking has grown as one of the most complex global concerns impacting practically all governments today. Various international publications and researchers on the subject have stated that human trafficking involves the exploitation of people for a variety of reasons, including forced labor, forced marriage, sexual exploitation, and organ 
Dr. Sasmita Patel et.al. The women as a commodity and marriage as a commercial opportunity: an investigation into the unpleasant truth of marriage trafficking in India.

trafficking, among others (Kakar \& Yousaf, 2021). This year's theme of UN places human trafficking victims at the campaign's core, emphasizing the significance of listening to and learning from the survivors of human trafficking. The campaign shows survivors as vital protagonists in the battle against human trafficking, emphasizing the critical role in devising effective measures to prevent this crime, identifying and rescuing victims, and assisting them on their journey (UNODC, 2021).

According to the Oxford Dictionary, trafficking is "the illegal movement of people, typically for forced labour or commercial sexual exploitation." Human trafficking is a dangerous crime and a severe violation of human rights. Each year, thousands of men, women, and children fall into the arms of human traffickers both at homeland and abroad. Almost every country globally is impacted by human trafficking, whether as a supplier, transit, or destination for victims (UNODC, 2021). According to the Palermo Protocol 2000 (UNODC, 2004), the legal definition of human trafficking is a crime that includes three elements:

i. The Act of recruiting, transporting, transferring, harbouring, or receiving a person;

ii. Using, e.g., coercion, deception, or abuse of vulnerability;

iii. These include sexual exploitation, slavery, and forced labour, among others.

Trafficking for commercial sexual exploitation is the pathetic form of sexual slavery (www.prajwala.com). It is a structured crime that leads to human vulnerabilities. For years, the abandoned trafficking was on the economically and socially disadvantaged, but with the advancement of the internet, even economically privileged portions of the community who are emotionally weak, have found themselves ensnared in conditions of exploitation. Many women and children have been misled, persuaded, pressured, or forced into sexual slavery in bogus ways.
According to Prajwala's data, it is difficult to count the victims, but it is predicted that 3 million women and children are trafficked for the intention of commercial sexual exploitation, with 45 percent of them being youngsters.

Human trafficking victims were identified and reported in 148 countries in 2018 is about 50,000 (UN, 2021). Fifty percent of the detected victims are trafficked for sexual exploitation, and 38 percent were for forced labor. Traffickers' primary target is females, and in all victims of trafficking, 46 percent in women and 19 percent girls, respectively (UN, 2021). While considering globally, one in every three victims was detected as a child. The number of victims of child trafficking has been tripled, and boys trafficking has been increased five times more in the past 15 year (UN, 2021). Child marriage is any formal or informal marriage between a child under 18 and an adult or another child (UNICEF, 2020). Child marriage trafficking entails the supply, delivery, recruitment, procurement, capture, removal, transportation, transfer, harboring, sale, exchange, lease, disposal, or receiving of a child across and within country borders, with or without means, for exploitation by the name of marriage (Warria, 2017).

India is the second-largest populated country globally and, as per the 2011 Census, has more than 662.90 million population of women. Even though women occupy $48.04 \%$ of the total population, their social status is not satisfactory. If we take the words of Mahatma Gandhi, "the progress of the country is determined by the social status of women in the country,"; and it is unfortunate to say that, for women, we have not been able to provide a safer place in our country. In the Global Slavery Index 2018, India's rank is 53 out of 167 countries. India ranked ninth most dangerous country for women, ranked 5th for intimate partner violence $(37.2 \%)$, and first in Gender Inequality Index (Review, 2021). According to NCRB reports, 6616 cases of human trafficking were registered in India in 2019, 
Dr. Sasmita Patel et.al. The women as a commodity and marriage as a commercial opportunity: an investigation into the unpleasant truth of marriage trafficking in India.

5788 in 2018, and 5900 in 2017 (NCRB reports 2019, 2018, 2017). Compared with 2017 and 2018, the number of human trafficking cases in 2019 found a remarkable increase. There is also an increase seen in forced marriage trafficking, sexual exploitation, and forced labor. In 2019, Delhi, the national capital, placed second in child trafficking, the number is 536; Rajasthan has the highest number of child trafficking i.e 653, in that 636 boys and 17 girls; according to the. Maharashtra's highest number of human trafficking cases is 986,95 to minors and 891 to victims above 18 years old; forced marriage human trafficking high in Assam is 65 and second for Kerala- 42 (NCRB report, 2019).

The power structure among men and women is entirely different in our society. Since our community is male-dominated and routed with patriarchal doctrines, women have a passive role in society. Because of these imbalances in the power structure, the situation of women is vulnerable. They face various gender-based violence, domestic violence, intimate partner violence, dowry-related issues, workplace violence, trafficking etc. Among these problems, trafficking is one of the most indiscriminate crimes happening around the globe that affect all categories of people, irrespective of gender, class (whether rich or poor), color (black or white), educated or uneducated, married or unmarried, minor or significant, disabled, or suffering from diseases (UNODC, UNODC, 2021). Trafficking of men happens with the intention of beggary (children), organ transplant, child labor, forced or bonded labor, and trafficking of women happens, in addition to the reasons as mentioned earlier, with few other reasons such as commercial sex work, marriage, and surrogacy (Trafficking in Person's Report 2019, Department of States, USA). Forced marriage is considered involuntary servitude under the definition of human trafficking in the Trafficking Victims Protection Act (TVPA) 2000. The TVPA defines involuntary servitude as a "condition of servitude induced through any scheme, plan, or pattern intended to cause a person to believe that, if the person did not enter into or continue in such condition, that person or another person would suffer serious harm or physical restraint; or the abuse or threatened abuse of the legal process" (Teekah \& Sheehan, 2019).

Thousands of Indians are trafficked every day in India to various locations for forced labor, sexual exploitation, forced marriage, and the sale or purchase of organs. They have little control over their bodies and lives and must survive in brothels, guesthouses, industries, farms, dance bars, and even the homes of well-off Indians. Victimization of the poor and defenseless has disqualified them from the human race, and they are treated in the market as if they were animals or vegetables (Singh, 2017).

\section{Objectives of the Present Study}

The paper is based on the following three objectives.

1. To study the contributing factors of bride trafficking in India

2. To understand the further consequences of bride trafficking in India

3. To critically analyze the existing legislations and provisions related to trafficking in India

\section{METHODOLOGY}

Our society treats women as a commodity and marriage as a commercial opportunity. Here, the study investigates the inimical reality of marriage trafficking in India. It has used secondary data primarily collected from journal articles, newspapers, and several online sources. It has reviewed and analyzed the contributing factors and the consequences of bride trafficking in India. At the same time, it has tried to critically analyze the existing legislations and affirmative provisions and their implications to prevent the said issue. Even the international studies are reviewed to comprehend the problem more vividly. In due process, the study also could identify 
Dr. Sasmita Patel et.al. The women as a commodity and marriage as a commercial opportunity: an investigation into the unpleasant truth of marriage trafficking in India.

the flashpoint areas and how these are tactfully happening with customary affiliations in different parts of India. Based on the three above stated objectives, the researchers have categorized the whole analysis and the findings into three major sub-themes which have included all nuances of the whole scenario of bride trafficking in India from a wider spectrum.

\section{Understanding the Contributing Factors of Bride Trafficking in India}

Various researchers in their studies have pointed out the contributing factors of bride trafficking in India. The most relevant studies established phenomena and supporting data are extracted classified and analyzed under the below-mentioned subheadings.

\section{Poverty and Economic Backwardness}

Sarkar (2016), in his article "Child Marriage Trafficking in India; Victims of Sexual and Gender-Based Violence", states that poor women are victims of marriage trafficking, and traffickers target the most vulnerable, deprived ones. Poverty is becoming a more significant reason for child marriage in India. Also, Choudhary, R. (2014) points out that these brides' families are very impoverished, frequently falling below the poverty line; they have little or no land assets and rely on seasonal low-paying agricultural wage jobs. Due to the dowry practice system in India, poor parents were seeing the girl child as a burden for them. The bride's family gives the dowry to the groom's family; if the girl child is marrying in early and dowry also becomes less. This article also identified the significant factors for bride trafficking. Social vulnerability towards religion, caste, creed are also the reasons for the same. The deprived family will see the girl after 14 as a burden. This article mainly focused on bride trafficking in Haryana state, India (Upadhyay, 2020).

$$
\text { However, Prakash and }
$$

Vadlamannati, in their article, say that increased male-child preference and neglecting of daughters occur in several Indian states, despite the country's strong economic growth, rise in prosperity, and progress in education literacy, and healthcare. Authors telling the main reason for male-child preference in India is the supposed economic helpfulness of having sons (Prakash \& Vadlamannati, 2019). In comparison, Valasseri (2014) talks about lakhs of money being required to spend on a girl's wedding, which becomes a significant challenge to a low-income family (Valasseri, 2014). This article is based life of brides after the Mysore Kalyanam in Kerala state, India. Here also discussing the economic burden of the girl child.

Here, in the reviewed articles, the authors spoke of poverty and economic backwardness, which are significant contributing factors to bride trafficking. Through these reviews, we can understand how these factors are leading to trafficking. Bride trafficking is mainly happening with poor and deprived women. Economic empowerment of women can be one of the major strategies to fight against these crimes happens between them. The economically empowered women can understand the value of education, can assert their rights, take better decisions, and have a respectful position in society. Women must have effective participation in the economy and different socio-political platforms, especially in the local governance, so that the status of women could be increased. These could, however, lead to the prevention and solution of the pressing problem of bride trafficking in India.

\section{Skewed Sex Ratio}

The article by Xiong (2021) investigates whether scarcity of marriageable women causes the trafficking of women for forced marriage in China, as well as the underlying factors of the trafficking. A sex ratio imbalance is an inordinate excess of one sex in the population. The term "sex ratio imbalance" refers to an overabundance of men in the context of this article. China's one-child policy and male preference make a skewed sex ratio leads severe male marriage squeeze. Huang \& Wen (2020), analyze 
geographical migration networks of bride trafficking crime from 2000 to 2018 in china. Their article also talks about the imbalanced sex ratio of bride trafficking. However, Stöckl, Kiss, Dong, \& Zimmermann says that China's patriarchal systems and one-child policies are examples of trafficking. An article points out that the one-child policy, along with a cultural demand for sons, has culminated in a skewed sex ratio in rural and poor China (Stöckl, Kiss, Dong, \& Zimmerman, 2017). However, an imbalance in the sex ratio will alter the age-specific chance of marriage, potentially resulting in a marriage squeeze. These articles say that male preference and the one-child policy make massive trouble in the Chinese government.

Vishwakarma, Shekar, \& Yadav (2019) investigated that the intensity of the male marriage squeeze is greater in Punjab, Uttar Pradesh, Mizoram, and Haryana, where the child sex ratio is more troubled than in other states. Unless the child sex ratio in such southern states is standard, Kerala, Kerala, and Tamil Nadu face a male marriage crunch. Historically, these states faced a female marriage squeeze. Their article points out the marriage crunch throughout states in India is that each state has a unique fertility and sex ratio level. Also, because of sex-selective abortions, the kid sex ratio is drastically skewed (Vishwakarma, Shekar, \& Yadav, 2019). According to the research by Blanchet (2005), the desire for purchased wives arose from locations where there were no girls. Because the technology for selective abortion of female fetuses was not available at the time, the skewed sex ratio may be attributed to feminine neglect, hard work, and a lack of health care.

Prakash \& Vadlamannati investigated the skewed sex ratio in India linked with girl trafficking. Authors say that 2011 Census of the Government of India, the child sex ratio (girls per 1,000 boys) in the age group 0-6 years is at its lowest since 1947. The ratio in 2011 was 914 girls for every 1,000 boys, compared to 927 to 1,000 in the preceding 2001 census, demonstrating a marked and continuing birth preference for boys over girls. The study reveals a 100 unit rise in the child sex ratios connected with a 0.635 percent increase in girl trafficking, using the panel data from 19802011 from 28 Indian states (Prakash \& Vadlamannati, 2019). Upadyay (2020), through his study, put forward that female feticide is the significant factor for bride trafficking. The skewed sex ratio is another contributing factor to bride trafficking. These articles reveal that gender differences especially male preference are the major concern for the skewed sex ratio. However, from the literature reviewed, it is understood that the increase of male preference increases bride trafficking in the country.

\section{Dowry}

Blanchet (2005) studied that dowry demands have hugely impacted poor Bengali parents who could not arrange their adolescent daughters. Simultaneously, the concern with purity demanded that girls marry at a young age. The researcher stated that the marriage and groom are decided by the girl's guardians generally in the Bengali families. The study stated that poor Bangladeshi parents are marrying their daughters in the Indian state like Uttar Pradesh. The pressure of society comes if the girl child is not getting married. Due to the fear of society, low-income families were sending their children to Uttar Pradesh. Valasseri (2004), tries to examine that in the Indian context, dowry is the most common practice associated with marriages. He revealed that the bride's family has to spend lakhs of rupees on the groom as dowry in the forms of ornaments, money, property, vehicles, and expensive gifts. He found out that the dowry amount for Mysore marriage is usually below as compared with the typical marriages.

In these circumstances, many traffickers play the role of marriage brokers, and they will approach the girl's family with grooms, those who demand less dowry than customary marriages (Valasseri, 2014). 
Dr. Sasmita Patel et.al. The women as a commodity and marriage as a commercial opportunity: an investigation into the unpleasant truth of marriage trafficking in India.

Also, Rakesh Chaudhary (2014), through his article, shows the reason for the inability to satisfy the excessive dowry demands made by local grooms, which forces them to form long-distance relationships, is the primary reason women choose 'dowry-free, no wedding expenditures' proposals made by Haryanvi or Rajasthani men.

Dowry is a significant problem of bride trafficking. These reviews can conclude that dowry is common in our society during marriage. The poor family is mostly being affected by the problem because of the incapability of giving dowry to the daughters. A considerable amount of money is needed to spend for marriage which leads them to multiple vulnerabilities, and many traffickers play like marriage brokers.

\section{Educational Background}

Educational backwardness is a leading corridor for bride trafficking. Sarkar (2016) stated that women in low-income families were unable to get an education; only they preferred male children to go and study because they think that after completing education, they will get a good job and male children can only look house effectively. Interestingly, Chaudhary (2014) revealed that most brides were bought from Haryana, Punjab, and Rajasthan. Due to the scarcity of girls in these areas, unemployed or illiterate youths cannot find wives within their society, leading to the bride-buying practice. However, in his study, Valasseri (2004) discloses that most respondents have significantly less education, unaware of legal procedures on divorce and compensation. It is understood that lack of education is responsible for the vulnerability, be it not educating the girl children, not finding brides for marriage, unawareness of many more social and legal complications. The above reviews concluded with the understanding that most trafficked women/ girls have less education and are unaware of legal procedures.

\section{Early Marriage}

In his article, Sarkar (2016) stated that early marriage happens when a child is much younger than 16 years old, primarily due to high illiteracy, poverty, and the economic condition of a girl's family. Girls who marry young are also forced into childbearing at a young age, which raises the risk of serious injury, baby death, starvation, and even maternal death. Early marriage is a contributing factor to bride trafficking. The literature shows that poverty and economic condition are also linked with early marriage, and early childbearing can cause maternal death. However, there are fewer amount of articles on child marriage trafficking and the related issues.

\section{Bride trafficking as a business}

Xiong (2021) investigated that women from other nations and those without physical or mental problems were sold at a greater price. The average price of trafficked women of foreign origin is consistently the highest. It is hardly surprising that trafficked women from neighboring nations prefer to be young, healthier, and physically more attractive. Purchased girls were immersed in a rural economy, where their labor and reproductive capabilities were fully utilized. The desire for purchased wives arose from locations where there were no girls. Purchased girls were frequently wedded to older men who had already been married. Sold girls lived monogamously in long-term marriages, had multiple children, and were utterly wed-locked (Blanchet, 2005).

Deebashree (2005), in her article, speaks that bride trafficking can be considered a business for the owners. Here, the commodity (bride) was bought for an insignificant amount, forced to work as slaves, treated as trash, and tortured continuously. The author conveys that the rise in bride trafficking can be attributed to this trade allowing women to be resold to anyone at higher prices. Thus, though the study can be understood that there are 
Dr. Sasmita Patel et.al. The women as a commodity and marriage as a commercial opportunity: an investigation into the unpleasant truth of marriage trafficking in India.

essentially no chances of losing money, profit, or initial investment; hugely profitable sector since the women can be trafficked and re-trafficked several times, and the trafficker can gain money at each stage (Deebashree, 2015), while Upadhyay (2020), discusses that it is a highly profitable business for traffickers, they traffick, sell and resell the innocent brides and make money. Even though society and the police are aware of this practice, they keep silent. Traffickers are finding new ways to traffic. Job offers, marriage, trapping in love-relationship, kidnapping, etc are how the traffickers traffick. Nowadays, bride trafficking has become a kind of very money-spinning business. They buy the bride and resell them at a very high price. Here, the author conveys that traffickers get huge money at each stage and this has become a shortcut way to make money.

\section{Society as a contributing factor}

Since the pre-1978 era, patriarchal systems, like the pervasive intention for men to marry and create male children for the existence of the family line, have led to a significant increase in bride prices in China. As a result, Chinese males who are forced to marry by their own families but lack significant money or other possessions are typically not regarded as socially suitable mates for women (Stöckl, Kiss, Dong, \& Zimmerman, 2017). Nevertheless, Banerjea (2020) discusses the silent approval of the society for bride trafficking in certain places. The author says that even though bride trafficking is illegal, it is practiced in states like Haryana, Karnataka, and Kerala. For several years, the practice has been taking place in those mentioned states. He investigated if the society were really against the practice, it would not have continued all these years. The societal approval happens in a silent mode. Many people attend marriages, the brides' family never does proper background checking of grooms. After marriage, society never supports the victim to escape from her exploitative husband and/or the family. Many news reports say such trafficked brides attempted to escape the trap, but they were forcefully sent back to their so-called husbands, families, or purchasers. He also reveals that the victim approaches the police for help, police will not take proper action; they hand over the victims to their husbands and families due to the pressure from family, society, and the common occurrence of the incident (Banerjea, 2020).

In some instances, Khap Panchayats have even punished these victims for shaming the community by attempting to escape. He is concluding that because of all these regressive attitudes from society, in most cases, trafficked brides will be left out with no one to support or help to save from these plights (Banerjea, 2020). Also, Jabir (2017) discloses that due to the social stigma associated with divorced/deserted women, the victims do not speak about the violence/crimes they are experiencing. In the same line, it is revealed that the patriarchal view of society closes all the possibilities for women to escape from such violence.

Thus, the ailing societal norms are also taken as one of the contributing factors of bride trafficking. In many places, these practices are continuing with the very silent praxis of society, doesn't matter whether the girl faces brutal torture or physical and sexual abuse in her marriage, it doesn't encourage or support her to escape. Society doesn't stand with the girl, and the people blame the girl first and then her family. Bride trafficking is a big trap for young girls and women. Police and other governmental systems are sometimes unable to deal with the traffickers. Social stigma is one of the most challenging issues today. Many girls are not ready to speak about the violence happening against them in the fear of the persisting taboos and societal norms.

\section{Situation During Covid- 19}

According to BBC News (September 18, 2020), the COVID-19 epidemic caused an increase in child marriages marriage 
trafficking in India. In 2020, the Childline, a children's helpline, reported a $17 \%$ spike in emergency calls related to the early marriage of girls in June and July of this year compared to the same months in 2019. According to government officials, news reports show that more than 10 million migrant workers, many young men, fled to their native land and villages due to a lack of employment during the lockdown. The report points out that as a result, parents of young girls concerned about their daughters' safety and future possibilities are marrying them off to protect their daughters' wellbeing. Another factor is that parents are supposed to pay for significant marriages, yet budget constraints have restricted wedding size. Schools have been drivers of transformation in India, particularly in impoverished places such as the state of Odisha in the eastern state. It shows that they provide a safe location for girls to seek assistance from teachers and peers when their families pressure them to marry. However, a vital safety net has been lost (BBC NEWS September.18, 2020).

However, in Times of India's foreign correspondent (August 12, 2020) reports that after the Covid-19 outbreak halted the industry and forced the closure of schools in March, activists and officials in India's southern state of Tamil Nadu and western Maharashtra saw an unexpected trend: child weddings were on the rise (Srivastava, 2020). In the News 18 Sen(August 12, 2020), the border district of North 24 Parganas of West Bengal has long been a significant trafficking hotspot in India. Because of the district's porous borders with Bangladesh, it has become a hotbed for the trafficking of girls and women. News reports discussing the tragic impact of two tragedies, COVID-19 and Amphan, have increased the risk of trafficking more than ever. In the majority of these weddings, young girls were subjected to exploitation, abuse, marital rape, and captivity at the hands of their husbands and in-laws. He also stated that labor trafficking, child marriage trafficking, etc. are widespread (Sen, News 18, August 12, 2020).

Covid- 19 brought huge devastation for society. It affected all the sectors of society such as affecting education and job sectors, increasing violence against women, child trafficking, etc. Child marriage has been increased widely due to lack of schooling and poverty. Because of closing school, the children lost their safe place. Moreover, many of them became jobless and fell into the poverty line. Due to that, parents are afraid of the dowry, which also increases early marriage trafficking. It can be seen that every contributing factors are interconnecting. The above-discussed news reports talk about the importance of education and prevention of child marriage.

\section{Understanding the Consequences of Bride Trafficking in India}

Various studies pointed out the consequencing factors of bride trafficking in India. The literature which is most closer to the point of discussion is extracted and analyzed under the below stated different subheadings.

\section{Domestic Violence}

Valasseri (2014), in his study, mentioned that the woman will be considered a liability to her parental home and only as a sex object in her married life. After going to the groom's home, the brides started to experience cruel domestic violence. However, Banerjea (2020) says they were frequently confronted with financial difficulties and domestic violence. After reaching the husband's home, they can not return to their natal home, and they were restricted to access their rights in reproductive cases. Also, Jabir (2017) through his study, looks at the issues confronted in their marital home and the survival of the women after coming back to their natal home. Singh (2017), in his article, discussed the matrimonial rights that the bride has or not and the rights and responsibilities of the so-called husband. Violence perpetuates to get women to depart their homes. Domestic violence is a 
Dr. Sasmita Patel et.al. The women as a commodity and marriage as a commercial opportunity: an investigation into the unpleasant truth of marriage trafficking in India.

consequence of bride trafficking and vice-aversa. These studies show that the brides face brutal domestic violence even at home, leading to even her death. Cruelty against the bride in both places may also force her to get trafficked and put her into forced prostitution.

\section{Forced prostitution}

Upadhyay (2020), in his article, discusses the extreme side of marriage, bride trafficking is a forced sale, resale, and purchase of girls/ women in the name of marriage. Bride trafficking is becoming forced slavery for women. However, in the supporting line, Banerjea (2020) says that society never supports the victim to escape from her exploitative husband. Nevertheless, Sarkar (2016), reveals that the thrown-out brides face social stigma, and society will not offer support and help. These girls are forced to get into prostitution. Forced prostitution is an outcome of trafficking. Through these reviewed articles one can better comprehend how the societal silence indirectly supports trafficking and further forced prostitution which is the well-grounded reflection of forced slavery.

\section{Maternal health}

Again Sarkar (2016) reveals that the girls who marry young are also forced into childbearing at a young age, which raises the risk of serious injury, baby death, starvation, and even maternal death. There is a considerable risk for trafficked brides during the maternal period, leading to trauma, even fatal diseases, and death. During the pregnancy, they face various kinds of cruelty from the traffickers or groom which impairs them and their children physically and mentally. This kind of trafficking has severe consequences for the mental health of the bride.

\section{The helplessness of women \& disappearance of human rights}

Blanchet (2005) reveals that sold girls lived monogamously in long-term marriages, had multiple children, and were utterly wed-locked. Also, in his article, Valasseri (2014) discloses the bride's situation after going to the groom's home. The brides started to experience massive negligence of human rights. Once they agree to the marriage, they get trapped and send their daughters to distant places. It is how usually bride trafficking happens. In the article "Situating marriage payments: bride-price and dowry among the Bedias of north India," Anuja Agrawal examines how marriage payments among the Bedia community. The way the Bedias talk about bride price conveys that Bedia wives are marketable goods. A Bedia family's rights in a woman through a bride-price payment are substantial since they imply control over her sexual, reproductive, and domestic labor. Thus, a widowed wife may be expected to cohabit with the husband's younger brother (Agrawal, 2014). However, he also said that their concept of "home" was distorted, many women have never experienced ownness towards their in-laws' house or the community. They frequently felt alienated, deserted, and their voice was suppressed. Banergee (2020), reveals that their freedom of movement and decision-making was severely limited, and they were denied fundamental reproductive and property rights.

Furthermore, the author discussed that these women were coping with fundamental concerns such as a water shortage and electricity, not to mention a severe lack of toilets and restrooms. Her ideas and emotions are also influenced by the social and familial norms that affect girls and women to believe that the part of their duty as a wife is to persist submissive, compromised, and engaged in care work, raising children, agricultural and household work with little financial security, respect, or fundamental freedom (Banerjea, 2020). The author also highlighted that the manifestation of love within those marriages is complex and often lacking. Women's impressions of their marriage life are mainly influenced by 
Dr. Sasmita Patel et.al. The women as a commodity and marriage as a commercial opportunity: an investigation into the unpleasant truth of marriage trafficking in India.

unpaid care responsibilities and informal labour (Banerjea, 2020).

The victims of bride trafficking often keep silent about the violence they face in most cases. The women are not permitted to speak with people or organize against their oppressors. Many things stop the victims from revealing the brutality they face, the most significant of which is that their husband's family will always watch them whenever they speak to somebody other than the family members (Banerjea, 2020). Human rights violations at different stages are most common happening with trafficked brides. They are rejected to get fundamental freedom and basic facilities like water, food, proper dressing etc.

\section{Natal home situation}

They were refused permission to visit their natal family because they had been bribed for it. The girls who left to marry were forced away and would never be supposed to come back (Blanchet, 2005). In the same line, Banerjea (2020) revealed that the majority of trafficking brides have little or no contact with their families. Humiliation and stigma associated with selling or being abducted for marriage, many women are labeled "lost" or abandoned by their families. Many women took solace in feeling that their marital house, or "sasural," was predestined for them. However, if the bride attempts to return to her natal family as a widow or even due to a marital breakdown, the Bedias expect monetary compensation from her family, which may exceed the original bride-price payment, though they may be unable to enforce this expectation (Agrawal, 2014). Jabir (2017), in his study, reveals that they also wish to secure their family, save the pride of their own family, and do not want to be a burden to their parents. As a result, most deserted instances remained hidden. There is a growing recognition that forced marriage has a significant consequence on lesbian, gay, bisexual, and transgender people (Blanchet, 2005).
The natal home situation of the trafficked bride will be more worsen. Through the reviews, it is understood that there happens to be no contact with their family. If they try to return to the natal's home, they may face more cruelty from the husband and his family. Most of the brides have no home because by selling the home, they conducted the marriage. There is a chance of the husband's disappearance during pregnancy, and she needs to depend entirely on the natal's home at the time. If she escapes somehow then try not to come back to the home as there may be violence or heavy monetary charge on the poor parents. Many times she may not have welcoming parents due to the stated reasons and thus, she cannot think of getting away from the violence which makes her voiceless and more vulnerable.

\section{Critical Analysis of the Existing Legislations and Provisions Related to Trafficking in India}

There are various laws against bride trafficking in India. The Immoral Trafficking Prevention Act (ITPA), the Bonded Labour Abolition Act, the Juvenile Justice Act, the Child Labour Act, and parts of the Indian Penal Code are all used to penalize trafficking for commercial sexual exploitation forced labor (Banarjee, 2020).

The Indian Constitution, the supreme legislation of the land, prohibits human trafficking. Article 23 of the Constitution expressly forbids "trafficking in human beings and beggars, as well as any comparable forms of forced labor." Article 24 of the Indian constitution also prohibits the employment of children under the age of 14 in factories, mines, or other hazardous occupations. Other fundamental rights enshrined in the Constitution that are relevant to trafficking are Article 14 on equality before the law, Article 15 on the prohibition of discrimination based on religion, caste, race, sex, or place of birth, and Article 21 on the protection of life and personal liberty and except in limited circumstances, Article 22 protects from 
Dr. Sasmita Patel et.al. The women as a commodity and marriage as a commercial opportunity: an investigation into the unpleasant truth of marriage trafficking in India.

arrest and detention (Rao \& Hanumantha, 2014).

\section{Immoral Trafficking Act (ITPA)- 1986}

The Immoral Traffic (Prevention) Act, 1986, initially the Suppression of Immoral Traffic in Women and Girls (SITA), 1956, is the central legislation dealing with trafficking in India and only addresses one face, namely prostitution or commercial sexual exploitation (Bhatty, 2017). It also provides welfare measures aimed at victim rehabilitation, such as establishing and managing protective homes by state legislatures. Unfortunately, even as a statute dealing with sexual exploitation, it falls short.

Bhatty explains even though the Act's title mentions trafficking, it lacks a proper definition of trafficking. Moreover, the Act does not fully describe commercial sexual exploitation. Instead, the emphasis is on designating brothels as sites of commercial sexual exploitation and prosecuting those who facilitate commercial sexual exploitation in brothels (Bhatty, 2017). He adds that the Act has not clearly defined whether human trafficking and engaging in prostitution are illegal. However, Goel discusses that the term "prostitute" is also not adequately defined in the Act since it is defined in Section 2 clause (f) as "the sexual exploitation or abuse of persons for commercial objectives, and the expression "prostitute" shall be construed accordingly." As a result, there must be a commercial objective, which means that the prostitute must accept money, but this ignores circumstances when they are labeled as prostitutes even when they were compelled to be so, and the money from customers went to brothel operators (Goel, 2019). One of the most significant discrepancies in the Act is the term "Immoral." It puts a moral component to the Act. As a result, the Act of prostitution, which is the source of the majority of trafficking, is viewed as immoral and unlawful, although the Act's drafters should have kept the topic completely legal (Goel, 2019).

The Act does not address the existing practice of recruiting girls into prostitution- the name of religion, such as devadasis. The explicit mention of socioreligious activities, which are not excluded from punishment under the law, would go a long way in the direction of ending this type of sexual exploitation (Bhatty, 2017). Bhatty also explains that the ITPA's sentence of 7 years in prison for trafficking offenses is lenient, particularly in children, even though a provision for life imprisonment exists in certain situations. The Act fails to address the cross-border features of trafficking (including inter-state trafficking) (Bhatty, 2017).

Many girls because of their vulnerability choose sex work as their profession, but if they give up the profession, our society may not welcome and allow them to be back in the family. So, there should be some provision for community-based rehabilitation of the victims. Also, there should be some provisions of reforms along with punishment even for the offenders under this Act. Looking into the present scenario, amendments should be brought in the Act in the discussed lines.

\section{Prohibition of Child Marriage Act 2006}

The Child Marriage Restraint Act, 1929, was repealed by the Prohibition of Child Marriage Act (PCMA) in 2006. It has been alleged that traffickers, in some parts of the country, are taking advantage of the horrible custom of underage marriage to target innocent girls for trafficking. As an outcome, the Act must be implemented to address the traffickers' mode of operation. Kolisetty explains that the PCMA Act defined child marriage as the marriage of a boy under 21 and a girl under 18. The Act also made reasonable adjustments, such as increasing the maximum penalty to two years in prison and a fine of one lakh Indian rupee. If the marriage is stated null and void, the Act requires the return of all 
Dr. Sasmita Patel et.al. The women as a commodity and marriage as a commercial opportunity: an investigation into the unpleasant truth of marriage trafficking in India.

assets, money, presents, and ornaments supplied to the other party, as well as an order of support for the former wife. The Act also mandates for governmentappointed Child Marriage Prohibition Officers to work to stop child marriages; At same time, this is a fine idea, in theory, it is unclear whether and to what extent they are actually in practice (Kolisetty, 2015).

Also, he elaborated that the Act did not, however, make every child's marriage automatically null, instead of making them void only when the child is "taken or enticed" from the care of a guardian, in circumstances of compulsion, fraud, or trafficking, and when committed in violation of an injunction. Furthermore, it is controversial that the Act criminalizes those who undergo child marriages, most often parents or close relatives, without considering the reasons for child marriage: poverty, a lack of educational opportunities, a family's fear for the security of their daughters, and dowry demand harassment (Kolisetty, 2015). Child marriage is one of the biggest trauma in our country that violates various rights of children. Even in this developing era, many of the Indian states were practicing child marriages as a part of the custom. Thus, with the necessary amendments, the implementation of the Act should be done effectively and efficiently as to protect the children from child marriages and the risk of further trafficking.

\section{Juvenile Justice (Care and Protection of Children) Act}

The Act since its' effect on January 15, 2016, has since drawn a lot of criticism, criticism, and intense scrutiny for its attitude to children who conflict with the law (Tyagi, 2020). Tyagi points out that we must implement reforms to our juvenile justice system. The Juvenile Justice (Care and Protection of Children) Act of 2015, on the other hand, is not the solution to this dilemma. Letting children be tried as adults and penalized effectively wrecks their life in such a way that they do not even have a chance to rehabilitate themselves for mistakes they made as innocent youngsters. India's justice system has always been reformative because it attempts to reintegrate convicts into society as good Samaritans rather than outcasts. The modifications in the law addressing minors' ages were enacted in response to concerns that rising adolescent crime rates would stymie society's growth. Because of these incorrect beliefs, politicians have taken a strong position on juvenile law (Tyagi, 2020). In JJ Act, there is no scientific or logical reason given total rehabilitation for the child in conflict with law within a maximum of 3 years. Also, in JJ Act 2015, violating Article 14 and Article 15 (3) that children 16- 18 years are as culpable as adults and are competent to stand trial in an adult court. Transfer of adult court under clause 19 (3) denying the right to deal with the child-friendly atmosphere of JJ board, depriving the right to privacy, and violating the best interest provided under JJ Act 2000.

\section{Child and Adolescent Labour (Prohibition and Regulation) Act 1986}

India's Nobel laureate and child rights activist Kailash Satyarthi said he was disappointed by the amended Child and Adolescent Labour (Prohibition and Regulation) Act 1986, calling it a "missed opportunity." "The definition of family and family enterprises is flawed. This law uses Indian family values to justify the economic exploitation of children. It is misleading the society by blurring the lines between learning in a family and working in a family enterprise," he said in a statement. Here, the child is defined as age below 14 and adolescent age 14- 18 by taking the Right of Children to Free and Compulsory Education Act, 2009. However, in the JJ Act definition of a child is below 18 years which is not considered. UNCRC also defined a child as the same as to JJ Act. Also, here they are ignoring children working in family-based enterprises. These works may lead to sexual, physical, emotional exploitation also. In the 1986 Act, 16 occupations and 65 processes were listed as hazardous, but now it is 
Dr. Sasmita Patel et.al. The women as a commodity and marriage as a commercial opportunity: an investigation into the unpleasant truth of marriage trafficking in India.

replaced by three occupations and 29 processes mentioned in Factories Act, 1948 covering the only organized sector.

\section{Karnataka Devadasi (Prohibition of Dedication) Act, 1982}

The State Legislature passed the Karnataka Devadasis (Prohibition of Dedication) Act in 1982, published in the Gazette by the government in 1984. The practice of dedicating any lady as a Devadasi is declared illegal and outlawed by the Act (Kothari, 2019). Act of dedication of any girl with or without consent of the dedicated persons engaging her in prostitution is unlawful and punishable. The KDPD Act declares devotion to be illegal and void with or without the Devadasi's agreement. As a result, dedication cannot prevent the girl from engaging in a legally binding marriage (Wilson, Raman, \& Giliyal, 2018). A person who "performs, permits, participates in, or aids in the performance of any ceremony or act for dedication" may be sentenced to three years in prison and a fine of up to two thousand rupees. Because the dedicating procedure is more of a family matter, the Act classifies the participation of guardians, family members, and relatives as a more serious offense with a more significant penalty. For KDPD Act, a minimum of two years in jail and a penalty of two thousand rupees, a maximum of five years in prison, and a fine of five thousand rupees (Wilson, Raman, \& Giliyal, 2018). Still, it is practiced in Karnataka rural areas, and also Act should provide the custody, protection, rehabilitation and welfare of Devadasis.

\section{Andhra Pradesh Devadasi (Prohibiting Dedication) Act, 1989}

The Andhra Pradesh Devadasi Prohibition of Dedication Act (AP Act) was passed in 1988. The Act defines dedication as any tali with jakini or tying a woman with a garland to a Garnda Khambham, Dharana, and Deeksha and declares such ritual to be illegal and void (Kothari, 2019). According to this Act, free education, economic assistance, and rehabilitation schemes were provided for Devadasis.

\section{Goa Children's Act, 2003}

This Act is precisely defined in trafficking. The definition of sexual assault includes all forms of sexual exploitation. The manager and owner are responsible for the safety of minors or youngsters on hotel grounds. There are strict rules regarding children's protection and the publication of pornographic materials. In GCA 2003, the definition of the child, the rape victim of the child should be below the age of 16 years. It needs to be deleted then only can provide equal justice to victims below 18 years of all kinds of sexual offenses (Nadkarni, 2019). Government cooperation is necessary to implement GCA Act.

8. Ujjawala Scheme for prevention of trafficking and rescue, rehabilitation and reintegration of victims of trafficking, 2007

The scheme is open to women and children at risk of being victims of trafficking for commercial sexual exploitation. Beneficiaries can learn more about the scheme by contacting the Ministry of Women and Child Development (Ministry of Women and Child Development, 2016). Ujjawala was very successful like any other government program. The schemes' main components are prevention, rescue, rehabilitation, reintegration, repatriation. This scheme molded women's empowerment and provided good lies for children who were the victims of trafficking and sexual exploitation. NGOs implement this scheme

\section{Integrated National Plan of Action to Prevent and Combat Trafficking in Human Beings especially Women and Children}

The national plan was developed through a consultative process including all relevant Ministries and other stakeholders that the Government of India has adopted in the Ministry of Women and Child Development. This strategy addresses all 
areas of prevention, rescue, case registration, investigations, prosecution, conviction, cross-border trafficking issues, victim rehabilitation, repatriation, and reintegration.

Many legislations and provisions exist in India to prevent trafficking, but those are not efficiently working; because of that, India faces different issues. There are many loopholes in the legislation itself; for example, in the Child Labour Act, the child's age is 14 , and in JJ Act, it is 18 . The citizens are unaware of the legislation, and the Acts' language is complicated for everyone. It should make it easier to understand and ensure that every provision provided for the citizen is reaching in the right hands. If the government is not checking, we cannot prevent the situation, develop our country, and achieve sustainable goals.

\section{CONCLUSION}

Bride trafficking is deep-rooted in our society with different reflections. Thus, it can only be eliminated via cultural renaissance and community sensitization along with strong enforcement of the laws. This phenomenon is more similar to the demand and supply aspects of the market. The situation will persist till there is a demand for brides in places with skewed sex ratios and a disproportionately lower number of girls relative to boys. Thus, female foeticide and infanticide must be outlawed or curtailed at the very least to maintain a lid on the by-products of this phenomenon, such as bride trafficking, and it has become a universal trend in today's world.

Brides from economically deprived regions of east and south India are purchased for marriages. Girls are trafficked and sold by spouses and agents to men looking for girls to marry. These brides are tightly controlled so that the women do not escape. These women have a difficult life because they cannot make their own choices and are considered slaves. A girl, who should be in school at the young age of 14 or 15 to develop her future in the right direction with fair chances made accessible to her, is compelled into the so-called institution of marriage with men double or triple her age. Certain girls labor as domestic slaves during the day and forced prostitution at night reveal their awful situation. Several methods of intervention can be used to prevent human trafficking. It must concentrate on public sensitization and awareness and susceptible regions that create a climate conducive to human trafficking.

However, the study suggests that the existing legislation should be amended to include the necessary provisions which were discussed above and it should be more vigilant in inter-state and border marriages. Rehabilitation and support services should be provided for the women victims and counseling services to recover from the trauma. For their well-being, livelihood training also should be given to them. Bride trafficking is happening between lowincome families, and they cannot accommodate the education for female children. So, it is necessary to promote education among women. Social awareness is necessary to stop this kind of social evil from society: should give awareness on child marriage, trafficking, marital abuse, domestic violence dowry; need awareness on what is marriage and divorce also laws and programs regarding anti-trafficking. Panchayat level committee is necessary for understanding the socio-economic condition of women, and gender auditing should conduct in the educational sector to eliminate patriarchally thought. Moreover, empowerment of girls and women and the whole communities should be the final result for it to address the most pressing issue of bride trafficking in India.

\section{Acknowledgement: None}

Conflict of Interest: None

Source of Funding: None 
Dr. Sasmita Patel et.al. The women as a commodity and marriage as a commercial opportunity: an investigation into the unpleasant truth of marriage trafficking in India.

\section{REFERENCES}

1. Agrawal, A. (2014). Situating marriage payments: Bride-price and dowry among the Bedias of north India. SAGE Publications, 23-247.

2. Banerjea, S. (2020). Three women: stories of Indian trafficked brides. The Conversation.

3. Bhatty, K. (2017). A Review of the Immoral Traffic Prevention Act, 1986. Centre for Policy Research, 1-7.

4. Blanchet, T. (2005). Bangladeshi Girls Sold as Wives in North India. Indian Journal of Gender Studies, 305- 334.

5. Choudhary, R. (2014). Drought of Brides in the Fertile Lands: A Study in Context of India. Research gate.

6. Deebashree, M. (2015, January). The Pioneer.

https://www.dailypioneer.com/2015/sundayedition/slave-brides.html Retrieved on Sept. 2021

7. Ministry of Women and Child Development, GoI. (2016). https://wcd.nic.in/schemes/ujjawalacomprehensive-scheme-preventiontrafficking-and-rescue-rehabilitation-and-re Retrieved on September 2021

8. Flores, B. (2014). Waco Tribune Herald, May 18,2014

9. Goel, A. (2019). Comprehensive Analysis of Immoral Traffic Prevention Act, 1956. Avocat's \& Information Technology Cyberspace, 26- 60.

10. Huang, Z., \& Wen, W. (2020). Analysis of Geographical Migration Networks of Bride Trafficking Crime from 2000 to 2018 in China. Physica A.

11. Index, G. S. (2018). Global Slaver Index, http://www.globalslaveryindex.org/2018/fin dings/country-studies/india Retrieved on September 2021

12. Jabir, M. M. (2017). Mysore Marriages of Kerala. Journal of Social Work Education and Practice, 41-52.

13. Kakar, M. M., \& Yousaf, F. N. (2021). Gender, Political and Economic Instability, and Trafficking into Forced marriage. Routledge Taylor \& Francis Group, 1- 11.

14. Kolisetty, A. (2015, July 2). IntLawGrrls., from ilg2.org: https://ilg2.org/2015/07/02/child-marriagein-india-loopholes-in-the-law/ Retrieved on September 2021
15. Kothari, J. (2019). Intersections of Caste and Gender: implementation of Devadasi Prohibition laws. Bangalore: Center for Law and Policy Research.

16. Nadkarni, S. M. (2019). Implementation of the Goa Children's Act 2003 with Special Reference to Protection of the Girl Child in the State of Goa - A Critical Study.

17. BBC NEWS (2020, September 18) https://www.bbc.com/news/world-asiaindia-54186709

18. Prajwala. (n.d.). Trafficking. https://www.prajwalaindia.com/trafficking.h tml

19. Prakash, N., \& Vadlamannati, K. C. (2019). Girls for Sale? Child Sex Ratio and Girl Trafficking in India. Feminist Economics.

20. Rao, \& Hanumantha, K. (2014). A critical study on the law relating to prevention of immoral traffic in India. Shodhganga.

21. Review, W. P. (2021). World Population Review. Retrieved September 2021, from worldpopulationreview.com:

https://worldpopulationreview.com/countryrankings/most-dangerous-countries-forwomen

22. Sarkar, S. (2016). Child Marriage Trafficking in India: Victims of Sexual and Gender-Based Violence. Anthropology Now, 62-70.

23. Sen, S. (2020, August 12). News 18., from news18.com: Child Marriage or Trafficking: Choice Covid-19 and Cyclone Amphan Have Left For Bengal's Vulnerable, Retrieved on September 2021

24. Singh, N. (2017). Trafficked Bride: Whether A Dream From Hell to Heaven or a Reality of Sexual Exploitation: A Study. International Journal of Interdisciplinary Research in Arts and Humanities, 283-289.

25. Sorensen, L. (2019). Human Trafficking (p.14). New York: Greenhaven Publishing LLC.

26. Srivastava, R. (2020, August 12). India's Covid-19 lockdown threatens efforts to stop spikes in child marriage. Reuters.

27. Trafficking in Persons Report (2019). United States Department of State Publication

28. Stöckl, H., Kiss, L., Dong, D. T., \& Zimmerman, C. (2017). Trafficking of Vietnamese women and girls for marriage in China. Global Health Research and Policy, $1-9$. 
Dr. Sasmita Patel et.al. The women as a commodity and marriage as a commercial opportunity: an investigation into the unpleasant truth of marriage trafficking in India.

29. Teekah, A., \& Sheehan, W. (2019, December 11). Safe Horizone, https://www.safehorizon.org/programs/force d-marriage-human-trafficking Retrieved on September 2021

30. Tyagi, R. (2020). The Juvenile Justice (Care and Protection of Children) Act, 2015 Critical Analysis. Medium.

31. U. N. (2020). Interlinkages between Trafficking in Persons and marriage. English, Publishing and Library Section, United Nations Office at Vienna.

32. UN.

(2021).

https://www.un.org/en/observances/endhuman-trafficking-day Retrieved September 2021

33. UNICEF. (2020). https://www.unicef.org/protection/childmarriage\#: : :text=Child\%20marriage\%20ref ers\%20to\%20any,an\%20adult\%20or\%20an other $\% 20$ child.\&text=Child $\% 20$ marriage $\%$ 20is\%20often\%20the, disproportionately $\% 2$ 0affected\%20by\%20the\%20practice Retrieved on September 2021

34. UNODC. (2020). United Nations publication.

35. UNODC. https://www.unodc.org/toc/en/crimes/human
-trafficking.html Retrieved on September 2021

36. Upadhyay, D. N. (2020). A Study of Female Foeticide as Root Cause of Bride
Trafficking in State of Haryana. Indian Journal of Law and Justice, 142-159.

37. Valasseri, D. (2014). An Investigation into the Socio-cultural Background and Impacts of Mysore Kalyanam. An International Refereed e-Journal of Literary Explorations, 362-366.

38. Vishwakarma, M., Shekar, C., \& Yadav, A. (2019). Variations in Marriage Squeeze by Region, Religion, and Caste in India. Journal of Comparative Family Studies, 313- 330.

39. Warria, A. (2017). Forced child marriages as a form of child trafficking. Children and youth Service Review, 274- 279.

40. Wilson, B., Raman, S., \& Giliyal, A. (2018). A Qualitative Study of the Legal Dimensions of 'Devadasi' Dedication Phenomenon. We World.

41. Xiong, W. (2021). Does the Shortage of Marrigeable Women Induce the Trafficking o Women for Forced Marriage? Evidence From China. Violence Against Women, 123.

How to cite this article: Patel S, Arya CC. The women as a commodity and marriage as a commercial opportunity: an investigation into the unpleasant truth of marriage trafficking in India. International Journal of Research and Review. 2022; 9(1): 689-704. DOI: https://doi. org/10.52403/ijrr.20220180 